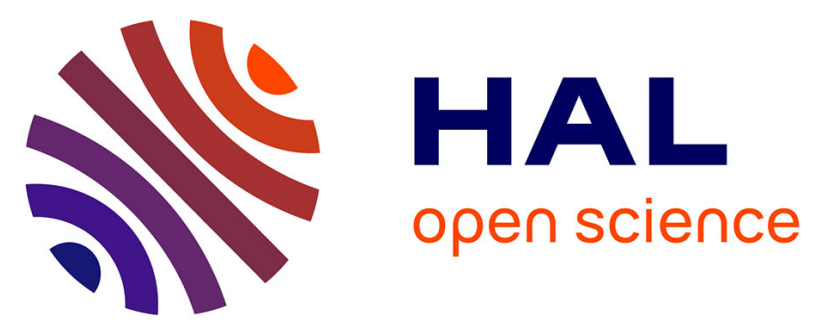

\title{
Pt Nanoparticles Supported on Porous Antimony-Doped Tin Dioxide Aerogel As Cathode Material for Proton-Exchange Membrane Fuel Cells: Electrocatalytic Activity and Degradation Mechanism
}

Gwenn Cognard, Guillaume Ozouf, Christian Beauger, Marian Chatenet, Frédéric Maillard

\section{To cite this version:}

Gwenn Cognard, Guillaume Ozouf, Christian Beauger, Marian Chatenet, Frédéric Maillard. Pt Nanoparticles Supported on Porous Antimony-Doped Tin Dioxide Aerogel As Cathode Material for Proton-Exchange Membrane Fuel Cells: Electrocatalytic Activity and Degradation Mechanism. ECS2016, The Electrochemical Society, May 2016, San Diego, United States. hal-01427028

\section{HAL Id: hal-01427028}

https://hal-mines-paristech.archives-ouvertes.fr/hal-01427028

Submitted on 5 Jan 2017

HAL is a multi-disciplinary open access archive for the deposit and dissemination of scientific research documents, whether they are published or not. The documents may come from teaching and research institutions in France or abroad, or from public or private research centers.
L'archive ouverte pluridisciplinaire HAL, est destinée au dépôt et à la diffusion de documents scientifiques de niveau recherche, publiés ou non, émanant des établissements d'enseignement et de recherche français ou étrangers, des laboratoires publics ou privés. 


\title{
Pt Nanoparticles Supported on Porous Antimony- Doped Tin Dioxide Aerogel as Cathode Material for Proton-Exchange Membrane Fuel Cells: Electrocatalytic Activity and Degradation Mechanism
}

\author{
Gwenn Cognard ${ }^{1,2}$, Guillaume Ozouf ${ }^{3}$, Christian Beauger ${ }^{3}$, Marian Chatenet ${ }^{1,2,4}$, Frederic \\ Maillard $^{1,2}$ \\ ${ }^{1}$ Univ. Grenoble Alpes, LEPMI, F-38000 Grenoble, France \\ ${ }^{2}$ CNRS, LEPMI, F-38000 Grenoble, France \\ ${ }^{3}$ MINES ParisTech, PSL Research University PERSEE - Centre procédés, énergies \\ renouvelables et systèmes énergétiques, CS 10207 rue Claude Daunesse, F-06904Sophia \\ Antipolis Cedex, France \\ ${ }^{4}$ French University Institute, Paris, France \\ gwenn.cognard@grenoble-inp.org
}

Proton Exchange Membrane Fuel Cells (PEMFC) are high-efficiency energy converters that can be deployed for mobile, transport and stationary applications in an eco-friendly manner. Nevertheless, their large-scale development requires further improvements, specifically regarding their lifetime in operation ${ }^{1}$. In abnormal PEMFC operating conditions, e.g. startup/shutdown events ${ }^{2}$ or localized fuel starvation ${ }^{3}$, the positive electrode may reach potentials of $1.5 \mathrm{~V}$ vs the reversible hydrogen electrode (RHE), which triggers extensive carbon support corrosion at the cathode side.

To tackle this problem, one of the solution studied in the literature is to use (more robust) carbon-free catalyst supports based on metal oxides ${ }^{4-6}$. To represent viable alternatives to conventional carbon blacks, metal-oxide substrates must fulfill three criteria: be electronconducting, resist corrosion and possess an opened porous structure compatible with facile ionomer insertion and efficient mass-transport properties.

This study focuses on aerogel structures obtained using a sol-gel route, based on antimony-doped tin dioxide (ATO) with different doping levels (0, 5, 10 and 15 at.\%). A Pt nanoparticles colloidal solution, obtained via a modified polyol route, was deposited on the ATO (Pt/ATO) featuring the best properties (10 at.\% Sb-doped $\mathrm{SnO}_{2}$ ), and, for comparison, on a Vulcan XC72 carbon $(\mathrm{Pt} / \mathrm{C})$ and on an undoped tin dioxide aerogel $\left(\mathrm{Pt} / \mathrm{SnO}_{2}\right)$. This strategy allowed the straightforward comparison of the $\mathrm{Pt} / \mathrm{ATO}, \mathrm{Pt} / \mathrm{C}$ and $\mathrm{Pt} / \mathrm{SnO}_{2}$ electrocatalysts in terms of catalytic activity for the oxygen reduction reaction (ORR) and durability.

A 2-fold enhancement in specific activity for the ORR was measured on Pt/ATO over the reference Pt/C, suggesting strong metal support interactions between the Pt nanoparticles and the ATO support. An accelerated stress test (AST) protocol $(5,000$ or 10,000 potential cycles 
between 1.0 and $1.5 \mathrm{~V}$ vs RHE) enabled to determine the robustness of the Pt/ATO and the Pt/C electrocatalysts during model start-up/shut-down events. Figure 1 illustrates that $\mathrm{Pt} / \mathrm{C}$ did not withstand operation in these conditions, as observed from the massive detachment of $\mathrm{Pt}$ nanoparticles from the carbon support following its corrosion. On the contrary, the Pt nanoparticles did not detach from the ATO support during ageing. However, evidences were provided that a core@shell structure with a Sb-poor surface covering a core with a Sb content close to the nominal forms during the AST. This core@shell structure restricts the capacity of the Pt nanoparticles to exchange electrons, as evidenced by the attenuated Pt surface oxide formation/reduction features, and the decreased catalytic activity for the ORR. 


\section{$\mathrm{Pt} / \mathrm{C}$ electrocatalyst}

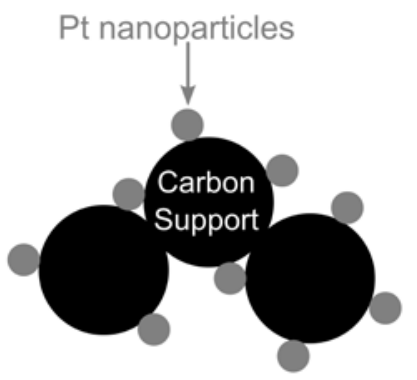

Accelerated stress test
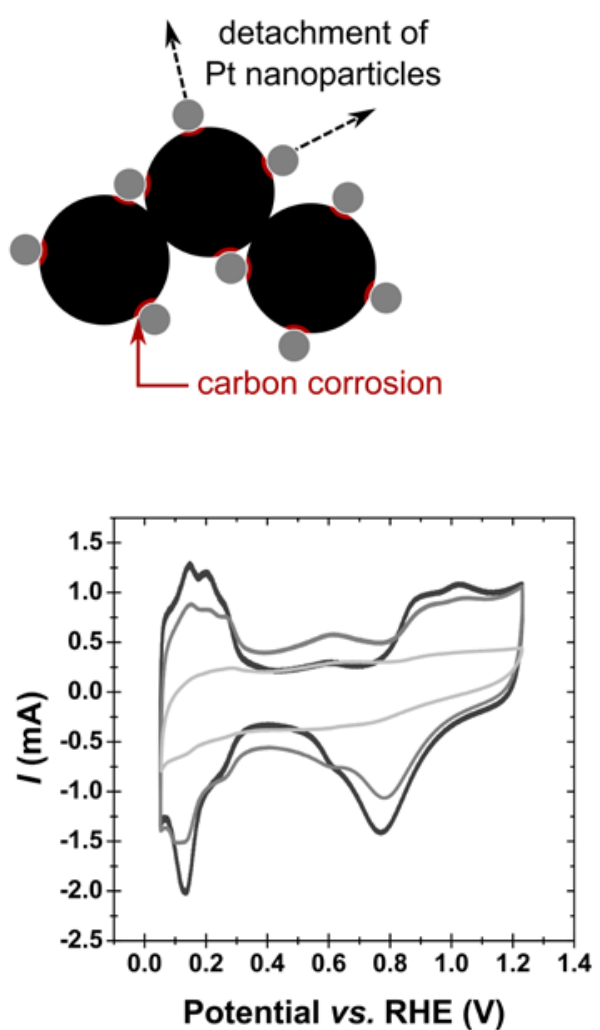

\section{Pt/ATO electrocatalyst}

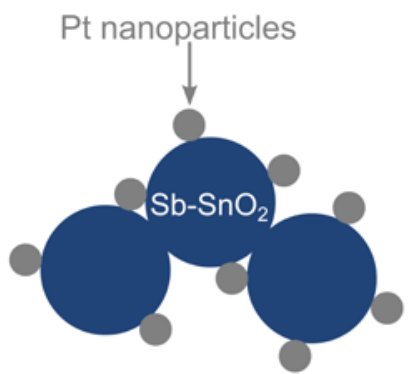

Accelerated stress test

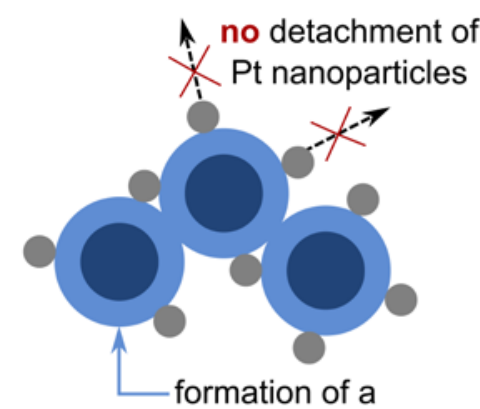

Sb-rich core@Sb-poor shell structure

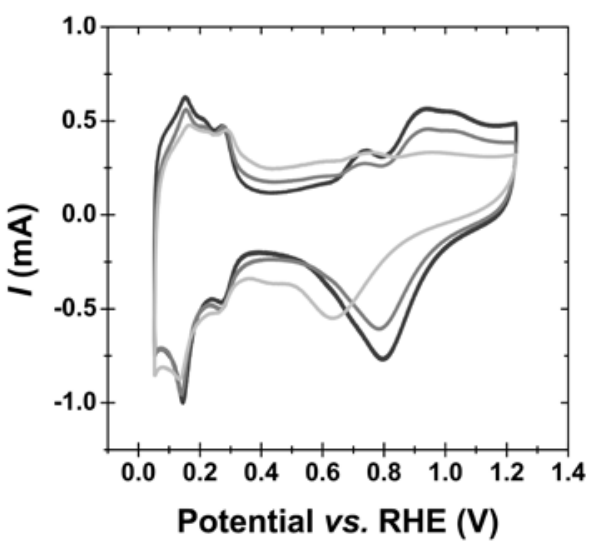

Fresh electrotalyst Aged $-5,000^{\text {th }}$ cycle Aged $-10,000^{\text {th }}$ cycle

Figure 1. Degradation of Pt nanoparticles supported on a carbon support and on ATO support during an accelerated stress test mimicking start-up/shut-down operating conditions.

\section{REFERENCES}

(1) Dubau, L.; Castanheira, L.; Maillard, F.; Chatenet, M.; Lottin, O.; Maranzana, G.; Dillet, J.; Lamibrac, A.; Perrin, J. C.; Moukheiber, E.; Elkaddouri, A.; De Moor, G.; Bas, C.; Flandin, L.; Caqué, N. Wiley Interdiscip. Rev. Energy Environ. 2014, 3 (6), 540-560.

(2) Ishigami, Y.; Takada, K.; Yano, H.; Inukai, J.; Uchida, M.; Nagumo, Y.; Hyakutake, T.; Nishide, H.; Watanabe, M. J. Power Sources 2011, 196 (6), 3003-3008. 
(3) Durst, J.; Lamibrac, A.; Charlot, F.; Dillet, J.; Castanheira, L. F.; Maranzana, G.; Dubau, L.; Maillard, F.; Chatenet, M.; Lottin, O. Appl. Catal. B Environ. 2013, 138-139, 416-426.

(4) Takabatake, Y.; Noda, Z.; Lyth, S. M.; Hayashi, A.; Sasaki, K. Int. J. Hydrogen Energy 2014, 39 (10), 5074-5082.

(5) Fabbri, E.; Rabis, A.; Kötz, R.; Schmidt, T. J. Phys. Chem. Chem. Phys. 2014, 16 (27), 13672-13681.

(6) Kakinuma, K.; Chino, Y.; Senoo, Y.; Uchida, M.; Kamino, T.; Uchida, H.; Deki, S.; Watanabe, M. Electrochim. Acta 2013, 110, 316-324. 